Kaganga: Jurnal Pendidikan Sejarah dan Riset Sosial Humaniora

Volume 2, Nomor 2, Desember 2019

e-ISSN : 2598-4934

p-ISSN : 2621-119X

DOI : https://doi.org/10.31539/kaganga.v2i2.1001

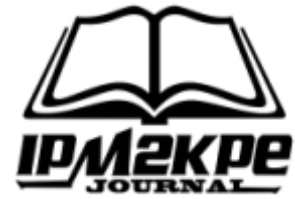

\title{
STRATEGI PELAKSANAAN PENDIDIKAN PAI BERWAWASAN MULTIKULTURAL DI SEKOLAH
}

\author{
Ahmad Asrin \\ Sekolah Tinggi Agama Islam Negeri (STAIN) Madina Sumatera Utara \\ ahmadasrin75@gmail.com
}

\begin{abstract}
ABSTRAK
Tulisan ini membahas mengenai bagaimana membangun dan mengembangkan mata pelajaran Pendidikan Agama Islam (PAI) berwawasan multikultual di Sekolah, adapun yang menjadi fokus pembahasan adalah bagaimana strategi dalam pendidikan yang berwawasan multikultural dan bagaimana pengembangannya di Sekolah. Metode yang digunakan dalam pembahasan ini adalah kwalitatif dengan pendekatan library research. Hasil pembahasan menggambarkan bahwa Penerapan pendidikan multikultural di Sekolah harus terintegrasi dengan berbagai mata pelajaran yang relevan dan didasarkan pada kondisi sosial anak dan bukan semata hasil adopsi dari konsep pendidikan multikultural bangsa lain dan pengembangan desain pendidikan multikultural di Sekolah terdiri dari tiga tahap, yaitu: menganalisis faktor-faktor potensial bernuansa multikultural, menetapkan pendekatan, metode, dan media pembelajaran berbasis multikultural, dan menyusunan rancangan pembelajaran berbasis multikultural. Simpulan penelitian ini penerepan pendidikan multikultural harus terintegrasi dengan berbagai mata pelajaran yang relevan dengan menghargai pluralitas dan heterogenetias.
\end{abstract}

Kata Kunci: Strategi Pelaksanaan, PAI, Wawasan Multikultural

\begin{abstract}
This paper discusses how to build and develop Islamic Religious Education (PAI) subjects with multicultural insights in Schools, while the focus of the discussion is how to strategy in education with multicultural insights and how to develop them in Schools. The method used in this discussion is qualitative research library approach. The results of the discussion illustrate that the application of multicultural education in schools must be integrated with a variety of relevant subjects and are based on the social conditions of children and not merely the adoption of multicultural education concepts of other nations and the development of multicultural education design in schools consists of three stages, namely: analyzing factors potential multicultural nuances, determining approaches, methods and media for multicultural learning, and developing multicultural based learning designs. The conclusion of this research is that the forerunners of multicultural education must be integrated with a variety of relevant subjects with respect to plurality and heterogeneity.
\end{abstract}

Keywords: Strategy of Implementation, PAI Subject, Multicultural Insights 


\section{PENDAHULUAN}

Sekolah merupakan lembaga pendidikan yang mempersiapkan peserta didik untuk menjadi generasi yang memiliki pengetahuan, wawasan/sikap dan tindakan di dalam kehidupan berbangsa dan bernegara yang memperhatikan latar belakang multikulturalisme. Kemajemukan bangsa Indonesia yang dimiliki adanya perbedaan budaya, suku, ras, agama dapat dijadikan sumber kekuatan yang sinergis dalam membangun kemajuan bangsa dan negara. Di dalam mengembangkan pendidikan multikultural di sekolah dapat menggunakan beberapa strategi baik di dalam kegiatan belajar mengajar, kegiatan-kegiatan sekolah yang lain maupun penerapan manajemen sekolah berbasis multikural yang menjadi penanggung jawab dan pemimipinya adalah kepala sekolah.

Ciri bangsa Indonesia yang pluralistik dan multikultural menyebabkan strategi kebudayaan nasional harus diisi dengan nilai-nilai yang tepat, di antaranya adalah prinsip mutualisme yaitu kebersamaan dan kerja sama yang memberi manfaat kepada semua pihak yang bekerja sama, bukan hanya searah dan menguntungkan satu pihak saja, berarti menekankan pada pentingnya memberikan kesempatan bagi berkembangnya masyarakat multikultural yang masing-masing harus diakui haknya untuk mengembangkan dirinya melalui kebudayaan mereka. Dengan demikian membangun dirinya, membangun tanah leluhurnya termasuk sebagai bagian dari tanah air Indonesia dengan didasari oleh sikap egalitarian, toleran dan demokratis (Munadlir, 2016).
Konsep multikulturalisme menunjuk pada pluralitas kebudayaan, sikap dan pemahaman untuk meresponnya. Hampir semua negara di dunia ini terbentuk dari keanekaragaman kebudayaan, maka multikulturalisme harus diterjemahkan ke dalam kebijakan dalam kehidupan masyarakat dan bangsa, sebagai pengelolaan perbedaan kebudayaan warga negara. Namun yang perlu diperhatikan adalah model multikural seperti apa yang dapat dikembangkan di suatu negara seperti di Indonesia (Munadlir, 2016).

Konsep multikultural sebenarnya telah diperhitungkan oleh bangsa Indonesia pada masa awal kemerdakaan. Namun pada praktiknya, peristiwa pengeboman tempat ibadah, tawuran antar pelajar, konflik antar etnis yang berbeda, terorisme, dan penistaan agama juga masih menggambarkan bahwa masih banyak masyarakat yang belum memaknai konsep multikultural tersebut secara utuh, sehingga diperlukan sebuah desain pendidikan multikultural yang bertujuan untuk menanamkan multikulturalisme pada diri masyarakat sejak dini (Husein: 2004).

\section{METODE PENELITIAN}

Penelitian ini menggunakan metode penelitian kepustakaan karena persioalan penelitian yang peneliti tulis hanya bisa dijawab lewat penelitian pustaka dan sebaliknya tidak mungkin mengharapan datanya dari riset lapangan. Berdasarkan pendapat Mestika Zed maka ada empat ciri utama studi pustaka: 1 . Bahwa peneliti berhadapan langsung 
dengan teks (nash) atau data angka dan bukan dengan pengetahuan langsung dari lapangan atau saksi mata berupa kejadia, orang atau benda-benda lainnya. 2. Data pustaka bersifat siap pakai artinya peneliti tidak pergi kemana- mana kecuali hanya berhadapan langsung dengan bahan sumber yang sudah tersedia diperpustakaan. 3. Bahwa data pustaka umumnya adalah sumber skunder, artinya bahwa peneliti memperoleh bahan dari tangan kedua dan bukan data orisinil dari tangan pertama dilapangan. 4. Bahwa kondisi data pustaka tidak dibatasi oleh ruang dan waktu (Mestika Zed, 2004).

\section{HASIL DAN PEMBAHASAN Pendidikan Multikulural}

Pendidikan multikultural secara etimologis berasal dari dua term yakni pendidikan dan multikulturtal. Pendidikan dapat diartikan sebagai proses pengembangan sikap dan tata laku seseorang atau sekelompok orang dalam usaha mendewasakan manusia melalui upaya pengajaran, pelatihan, proses, perbuatan, dan caracara yang mendidik. Sedangkan istilah multikultural sebenarnya merupakan kata dasar yang mendapat awalan. Kata dasar itu adalah kultur yang berarti kebudayaan, kesopanan, atau pemeliharaan sedang awalannya adalah multi yang berarti banyak, ragam, aneka. Dengan demikian multikultural berarti keragaman budaya, aneka, kesopanan, atau banyak pemeliharaan. Namun dalam tulisan ini lebih diartikan sebagai keragaman budaya sebagai aplikasi dari keragaman latarbelakang seseorang (Sunarto, 2015).
Pendidikan multikultural adalah sebuah tawaran model pendidikan yang mengusung ideologi yang memahami, menghormati, dan menghargai harkat dan martabat manusia di manapun dia berada dan dari manapun datangnya (secara ekonomi, sosial, budaya, etnis, bahasa, keyakinan, atau agama, dan negara). Sedangkan menurut para ahli,

1. H.A.R Tilaar, pendidikan multikultural merupakan suatu wacana lintas batas yang mengupas permasalahan mengenai keadilan sosial, musyawarah, dan hak asasi manusia, isu-isu politik, moral, edukasional dan agama.

2. Ainurrofiq Dawam, pendidikan multikultural adalah proses pengembangan seluruh potensi manusia yang menghargai pluralitas dan heterogenitas sebagai konsekuensi keragaman budaya etnis, suku, dan aliran (agama).

3. Prudence Crandall, pendidikan multikultural adalah pendidikan yang memperhatikan secara sungguh-sungguh terhadap latar belakang peserta didik baik dari aspek keragaman suku (etnis), ras, agama (aliran kepercayaam) dan budaya (kultur).

4. Zubaedi, pendidikan multikultural merupakan sebuah gerakan pembaharuan yang mengubah senua komponen pendidikan termasuk mengubah nilai dasar pendidikan, aturan prosedur, kurikulum, materi pengajaran, struktur organisasi dan kebijakan pemerintah yang merefleksikan pluralisme budaya sebagai realitas masyarakat Indonesia.

5. Andersen dan Custer, pendidikan multikultural adalah pedidikan 
mengenai keragaman budaya (Sunarto, 2015).

Dengan melihat dan memperhatikan berbagai pengertian pendidikan multikultural, disimpulkan bahwa pendidikan multikultural adalah sebuah proses pengembangan yang tidak mengenal sekat-sekat dalam interaksi manusia. Sebagai wahana pengembangan potensi, pendidikan multikultural adalah pendidikan yang menghargai heterogenitas dan pluralitas, pendidikan yang menjunjung tinggi nilai kebudayaan, etnis, suku, dan agama.

Berbicara tentang pendidikan Islam, para ahli Pendidikan Islam pendapat tentang asal kata Pendidikan Islam. Dalam hal ini, ada tiga term yang berkaitan berangsung dengan Pendidikan Islam, yakni tarbiyah, ta'dib, dan ta'lim. Secara singkat, istilah tarbiyah berasal dari akar kata rabb, yang dapat diartikan dengan tumbuh, berkembang, memelihara, merawat, mengatur dan menjaga kelestarian atas eksistensinya (Nizar, 2002).

Sedangkan istilah ta'lim berasal dari akar kata allama yang bearti mengajarkan. Istilah ta'dib sendiri berasal dari akar kata addaba yang berarti mendidik. Dari ketiga term tersebut, dapat kita pahami bahwa hakekat Pendidikan Islam adalah menjadikan manusia menjadi lebih baik. Baik itu melalui proses mengembangkan, merawat, mengatur, mendidik, mengajar dan sebagainya (Hawi \& Khoiri, 2017).

Hal ini sangat wajar, mengingat islam diturunkan kedunia ini untuk di jadikan pedoman hidup manusia, supaya manusia selamat di dunia dan akherat. Sehingga untuk mampu merealisasikan tujuan tersebut, diperlukan seperangkat proses sistemik yang kemudian disebut pendidikan.

Secara terminologi, Pendidikan Islam mempunyai bayak definisi, sesuai dengan sudut pandang dan subyektifitas yang mendefinisikannya. Berikut ini beberapa definisi Pendidikan Islam menurut para ahli:

Pendidikan Islam menurut Al Ghozali merupakan ibadah dan upaya meningkatkan kualitas diri. Selain itu, harus mampu mendekatkan diri kepada Allah SWT dan mendapatkan kebahagiaan dunia dan akherat (Nizar, 2002).

Sementara Ahmad Tafsir (1992) mendefinisikan Pendidikan Islam sebagai bimbingan yang diberikan oleh seseorang agar ia berkembang secara maksimal sesuai dengan ajaran Islam.

Menurut Nizar (2002) Pendidikan Islam adalah suatu sistem yang memungkinkan seseorang (peserta didik) dapat mengarahkan kehidupannya sesuai dengan ideologi Islam.

Achmadi (2005) menjelaskan Pendidikan Islam adalah segala usaha untuk memelihara dan mengembangkan fitrah manusia serta sumber daya manusia yang ada padanya menuju terbentuknya manusia seutuhnya (insan kamil) sesuai dengan norma Islam.

Multikulturalisme merupakan sebuah paham tentang realitas masyarakat yang beragam. Yang mana multikulturaliasme adalah sebuah respon dari sebuah fakta sosial yang beragam dan plural, sehingga keteraturan hidup yang humanis, demokratis dan berkeadilan akhirnya dapat di capai (Mustaqim, 2013).

Sejak awal, Islam turun ke dunia untuk tujuan kemanusian. Islam secara tegas dan jelas menyatakan 
bahwa Islam diturunkan untuk semesta alam. Artinya Islam lahir bukan semata-mata untuk umat Islam saja, tetapi semangat universalitas Islam sudah ditampakkan. Hal ini dapat kita lihat dari firman Allah tentang tujuan keterutusan Rasulullah, yang artinya tujuan diturunkannya Islam, yang kemudian kita kenal denga tujuan risalah. Dalam Surat al Anbiya' ayat 107, allah berfirman yang artinya: "Dan tiadalah Kami mengutus kamu (Muhammad), melainkan untuk (menjadi) rahmat bagi semesta alam" (Mustaqim, 2013).

Hal ini menegaskan betapa Islam diperuntukkan untuk semua manusia, bahkan semua alam dengan kergaman, perbedaan dan pluraliras yang mengitarinya. Pada dasarnya, Islam memandang multikulturalisme sebagai sebuah sunnatullah, keniscayaan alam yang tak terbantahkan. Perbedaan dan keragaman tersebut kemudian bukan menjadi alasan untuk saling berceraiberai, pecah-belah dan terjadi konflik. Dalam ayat lain dijelaskan bahwa keberagaman sosial ummat manusia yang ada, tidak lain adalah untuk menguji manusia supaya mereka mampu berbuat baik dan menciptakan kedamaian.

Sebagaimana yang termaktub dalam Surat al-Maidah ayat 4: "Untuk tiap-tiap umat diantara kamu, Kami berikan aturan dan jalan yang terang. Sekiranya Allah menghendaki, niscaya kamu dijadikan-Nya satu umat (saja), tetapi Allah hendak menguji kamu terhadap pemberian-Nya kepadamu, maka berlomba-lombalah berbuat kebajikan. Hanya kepada Allah-lah kembali kamu semuanya, lalu diberitahukan-Nya kepadamu apa yang telah kamu perselisihkan itu".
Dalam ayat ini dapat kita pahami bahwa Allah sengaja menjadikan ummat yang tidak satu ini dengan tujuan untuk menguji manusia, bagaimana mereka memahai perbedaan dan keragaman ummat itu. Selain itu, supaya manusia mau berlomba-lomba dalam kebaikan dan kebenaran, bukan malah untuk saling berselisih dan berkonflik(Mustaqim, 2013).

Strategi Sekolah Dalam Proses Pendidikan Berbasis Multikultural

Pendidikan multikultural adalah kegiatan belajar mengajar yang memberikan pengetahuan, pemahaman, sikap dan tindakan dalam mengembangakan atas kondisi perbedaan dan persamaan peserta didik terkait dengan jenis kelamin, ras, budaya, etnik dan agama. Proses pembelajaran ini dapat mengembangkan kondisi yang kondusif yang memandang keunikan peserta didik tanpa membedakan karakteristik latar belakang budayanya. Seorang guru perlu mengidentifikasi konsep tentang visi dan tujuan yang jelas mengenai pendidikan multikultural yang diajarkan dan dikembangkan di sekolah guna memberikan pengetahuan, sikap dan perilaku kepada seluruh peserta didik dan warga sekolah, sehingga suasana sekolah mampu mengembangkan dan mengimplementasikan interaksi edukatif dan interaksi sosial yang berdasarkan nilai-nilai multietnis dan multibudaya dalam lingkungan sekolah (Munadlir, 2016).

Implementasi pendidikan multikultural di sekolah memiliki beberapa spesifikasi. Dikatakan oleh Banks bahwa sekolah yang memiliki komitmen mengembangkan pluralisme harus nampak di dalam: (1) mengembangkan respek aktivitas 
sekolah terhadap keragaman etnik, (2) mengembangkan kohesivitas berdasarkan partisipasi bersama dari beberapa kelompok budaya, (3) memberi kesempatan maksimal untuk seluruh individu dan kelompok, (4) memfasilitasi perubahan konstruktif yang dapat meningkatkan martabat dan cita-cita demokrasi (Munadlir, 2016).

Proses pembelajaran yang dilakukan oleh guru-guru di sekolah perlu memperhatikan aspek-aspek di atas dengan cara-cara: pertama, mengajar bukanlah sekedar mengucapkan kata-kata, namun perlu memberi kesempatan peserta didik untuk mengembangkan dan aktif mencari serta mengolah pengetahuan/informasi yang diperoleh, sehingga menjadi suatu pemahaman yang terintegrasi dengan pengetahuan dan pengalaman yang dimiliki oleh peserta didik, kedua, pengembangan budaya agar dapat difahami dengan baik dan bersifat sesuai dengan realita kehidupan peserta didik, ketiga, peserta didik datang ke sekolah dengan pengetahuan awal yang dimilikinya, sehingga pembelajaran harus mampu mengkaitkan konsep baru dengan pengalaman yang telah dimilikinya (Munadlir, 2016).

Kegiatan pembelajaran pendidikan multikultural menurut Zubaidi adalah guru dituntut mau dan mampu menerapkan strategi pembelajaran kooperatif harus menerapkan di antaranya: adanya saling ketergantungan, adanya interaksi tatap muka yang membangun, pertanggung jawaban secara individu, ketrampilan sosial dan efektivitas proses pembelajaran dalam kelompok. Sekolah yang mengelola pendidikan berdasarkan multikultural

senantiasa menghormati, menghargai perbedaan yang ada pada warga sekolah dengan latar belakang nilai agama, suku, ras, bahasa, etnis dan golongan yang ada di sekolah, baik terhadap peserta didik, guru, karyawan, staf kependidikan maupun komite sekolah dan semua komponen yang berkepentingan dengan sekolah (Zubaedi, 2004).

Strategi pembelajaran yang diterapkan pendidik berdasarkan pendidikan multikultural di sekolah dengan mengacu pada proses pembelajaran yang dikembangkan oleh Sudjana yakni: (1) model pengembangan, maksudnya proses belajar mengajar dikembangkan sesuai dengan tahap-tahap perkembangan manusia, (2) model konsep diri, yakni pengembangan proses pembelajaran yang menekankan pada pentingnya kepribadian siswa yang kuat, dengan strategi pembelajarannya membantu siswa menjelaskan pikiran dan perasaan tentang dirinya dan nilainilai dasar kemanusiaan serta dapat merefleksikan pemahaman tentang dirinya, (3) model kepekaan dan orientasi kelompok, dimaksudkan untuk membantu keterbukaan pikiran dan kepekaan siswa terhadap orang lain. Strategi pembelajaran ini dapat dilakukan dengan melalui kelompok yang efektif, (4) model perluasan penyadaran proses belajar mengajar dimaksudkan untuk penyadaran terhadap kekuatan dan penggunaan fungsi otak kiri dan kanan, (5) model pembelajaran partisipatif, yakni proses pembelajaran berdasarkan kebutuhan, berorientasi pada tujuan, berpusat kepada peserta didik dan belajar berdasarkan pengalaman dalam kehidupan. Strategi pembelajaran ini melibatkan peserta didik yang dikelola dan 
diselenggarakan oleh guru dalam tiga (3) tahap kegiatan belajar mengajar yakni perencanaan, pelaksanaan dan evaluasi pembelajaran. Kegiatan ini dapat dapat dilakukan baik di sekolah maupun di luar sekolah (Zubaedi, 2004).

Realitas praktek pendidikan selama ini memberikan kesan bahwa pendidikan menganut asas subject matter oriented yang membebani peserta didik dengan informasiinformasi kognitif dan motorik yang kadang-kadang kurang relevan dengan kebutuhan dan tingkat perkembangan psikis mereka. Pengelolaan pengajaran yang ada memberi kesan terlalu beroriensi pada iptek, termasuk ketrampilan motorik yang terlalu berorientasi pada teknis. Asas ini memang dapat menghasilkan lulusan yang pandai, cerdas dan trampil, yang kurang diimbangi dengan kecerdasan emosional. Dalam usaha pelaksanaan demokratisasi pendidikan asas subject matter oriented dapat diubah menjadi student oriented. Orientasi pendidikan ini menekankan pada pertumbuhan, perkembangan dan kebutuhan peserta didik secara utuh, baik lahir maupun batin. Dalam hal ini kecerdasan otak memang penting, namun kecerdsankecerdasan yang lain, seperti: kecerdasan emosional, spiritual dan berbagai tipe kecerdasan lainnya, juga tidak kalah pentingnya (Munadlir, 2016).

Proses pendidikan di sekolah berbasis multikultural didasarkan pada gagasan filosofis tentang kebebasan, keadilan, kesederajatan dan perlindungan terhadap ha-hak manusia. Hakikat pendidikan multikultural mempersiapkan peserta didik untuk belajar secara aktif menuju pada kesamaan struktur dalam organisasi sekolah. Proses pendidikan berbasis multi kultural berusaha memberdayakan peserta didik untuk mengembangkan rasa hormat kepada orang yang berbeda budaya, memberi kesempatan untuk bekerja sama dengan orang lain yang berbeda etnis secara langsung, mengakui ketepatan dari pandanganpandangan budaya yang beragam, membantu peserta didik dalam mengembangkan kebanggaan terhadap warisan budaya mereka, menyadarkan peserta didik bahwa pertentangan nilai-nilai kehidupan sering menjadi penyebab konflik antara kelompok masyarakat (Munadlir, 2016).

\section{Pengembangan PAI Berwawasan Multikultural di Sekolah}

Pendidikan multikultural adalah sebuah proses pengem-bangan yang tidak mengenal sekat-sekat dalam interaksi manusia. Sebagai wahana pengembangan potensi, pendidikan multikultural adalah pendidikan yang menghargai heterogenitas dan pluralitas, pendidikan yang menjunjung tinggi nilai kebudayaan, etnis, suku, dan agama (Zubaedi, 2004).

$\begin{array}{lcr}\text { Tujuan } & \text { pendidikan } & \text { dengan } \\ \text { berbasis } & \text { multikultural } & \text { dapat } \\ \text { diidentifikasi: } & (1) & \text { untuk } \\ \text { memfungsikan } & \text { peranan } & \text { sekolah }\end{array}$
dalam memandang keberadaan siswa yang beraneka ragam; (2) untuk membantu siswa dalam membangun perlakuan yang positif terhadap perbedaan kultural, ras, etnik, kelompok keagamaan; (3) memberikan ketahanan siswa dengan cara mengajar mereka dalam mengambil keputusan dan keterampilan sosialnya; (4) untuk membantu peserta didik dalam membangun ketergantungan lintas budaya dan memberi gambaran positif kepada mereka mengenai 
perbedaan kelompok. Pendidikan multikultural (multicultural education) adalah proses penanaman cara hidup menghormati, tulus, dan toleran terhadap keanekaragaman budaya yang hidup di tengah-tengah masyarakat plural. Dengan pendidikan multikultural, diharapkan adanya kekenyalan dan kelenturan mental bangsa menghadapi benturan konflik sosial, sehingga persatuan bangsa tidak mudah patah dan retak (Kamal, 2018).

Pendidikan multikultural idealnya direncanakan dengan sebuah desain pengembangan kurikulum yang integratif, sequentif dan didukung dengan lingkungan serta struktur dan budaya yang bisa memberikan kontribusi positif terhadap pembinaan sikap dan perilaku multikultur. Oleh karena itu, Ibrahim telah mengemukakan beberapa prinsip yang harus dipatuhi dalam melaksanakan pendidikan multikultural, yaitu:

1. Pemilihan materi pelajaran harus terbuka secara budaya didasarkan pada siswa. Keterbukaan ini harus menyatukan opini-opini yang berlawanan dan interprestasiinterprestasi yang berbeda

2. Isi materi pelajaran yang dipilih harus mengandung perbedaan dan persamaan dalam lintas kelompok

3. Materi pelajaran yang dipilih harus sesuai dengan konteks waktu dan tempat

4. Pengajaran semua pelajaran harus menggambarkan dan dibangun berdasarkan pengalaman dan pengetahuan yang dibawa peserta didik ke kelas, dan

5. Pendidik hendaknya menggunakan model pembelajaran yang interaktif dan kontekstual agar supaya mudah dipahami oleh peserta didik (Ibrahim, 2008).

Selanjutnya, Tilaar juga mengemukakan empat prinsip yang perlu dipegang dalam menerapkan pendidikan multikultural, yaitu sebagai berikut.

1. Tujuanya membentuk "manusia budaya" dan menciptakan "masyarakat berbudaya (berperadaban).

2. Materinya mengajarkan nilai-nilai luhur kemanusian, nilai-nilai bangsa, dan nilai-nilai kelompok etnis (kultural),

3. Metodenya demokratis, yakni menghargai aspek-aspek perbedaan dan keberagaman budaya bangsa dan kelompok etnis (multiculturalis),

4. Evaluasinya ditentukan pada penilaian terhadap tingkah laku anak didik yang meliputi persepsi, apresiasi, dan tindakan terhadap budaya lainnya (Tilaar, 2004).

Adapun beberapa prinsip yang harus digunakan oleh guru dalam membuat media pembelajaran berbasis pendidikan multikultural adalah sebagai berikut:

1. Guru harus memperhatikan heterogenitas yang ada di dalam peserta didik, sehingga ketika akan membahas suatu topik harus dipertimbangkan agar tidak menimbulkan spekulasi negatif, karena perbedaan adalah masalah yang sensitif. Perlu diingat bahwa tujuan pendidikan multikultural salah satunya adalah untuk mengurangi prasangka dan diskriminasi di antara masyarakat yang plural

2. Guru dan siswa membuat media pembelajaran yang memberikan kesan positif dari setiap topik yang dibahas. Misalnya, ketika ada suatu budaya yang tidak 
sepatutnya ditiru, maka guru memberikan pengertian kepada para peserta didik bahwa tidak semua budaya sesuai dengan nilai dan norma yang berlaku di lingkungan mereka

3. Media pembelajaran multikultural harus memiliki unsur komitmen terhadap nilai yang tinggi di antara masyarakat yang majemuk

4. Memperhatikan kreativitas dalam menyajikan dan mengemas media pembelajaran yang menumbuhkan rasa ketertarikan pada peserta didik (Batubara, 2008).

Pembelajaran pendidikan agama Islam berwawasan multikultural di SMK adalah salah satu model pembelajaran pendidikan agama Islam yang dikaitkan pada keragaman yang ada, entah itu keragaman agama, etnis, bahasa dan lain sebagainya. Hal ini dilakukan karena banyak kita jumpai di sekolahsekolah (SMA) umum yang bukan bercirikan Islam di dalam satu kelas saja terdiri dari berbagai siswa yang sangat beragam sekali, ada yang berbeda etnis, agama, bahasa, suku, dan lain sebagainya (Kamal, 2018).

Untuk merancang strategi hubungan multikultural dan etnik dalam SMK dapat digolongkan kepada dua yakni pengalaman pribadi dan pengajaran yang dilakukan oleh guru. Dalam pengalaman pribadi dengan menciptakan pertama, siswa etnik minoritas dan mayoritas mempunyai status yang sama; kedua, mempunyai tugas yang sama; ketiga, bergaul, berhubungan, berkelanjutan dan berkembang bersama, keempat, berhubungan dengan fasilitas, gaya belajar guru, dan norma kelas tersebut. Dalam lingkungan pendidikan SMK, Guru PAI sebaiknya menggunakan metode mengajar yang efektif, dengan memperhatikan referensi latar budaya siswanya.

Guru PAI harus bertanya terlebih dahulu kepada diri sendiri, apakah ia sudah menampilkan perilaku dan sikap yang mencerminkan jiwa multikultural. analisis terhadap latar kondisi siswa. Secara alamiah siswa sudah menggambarkan masyarakat belajar yang multikultural. Latar belakang kultural siswa akan mempengaruhi gaya belajarnya. Agama, suku, ras/etnis dan golongan serta latar ekonomi orang tua, dapat menjadi stereotipe siswa ketika merespon stimulus di kelasnya, baik berupa pesan pembelajaran maupun pesan lain yang disampaikan oleh teman di kelasnya. Siswa bisa dipastikan memiliki pilihan menarik terhadap potensi budaya yang ada di daerah masing-masing (Kamal, 2018).

Analisis materi potensial yang relevan dengan pembelajaran yang berwawasan multikultural yang juga dapat diterapkan dalam pembelajaran pendidikan agama Islam, antara lain meliputi: Menghormati perbedaan antar teman (gaya pakaian, mata pencaharian, suku, agama, etnis dan budaya). Menampilkan perilaku yang didasari oleh keyakinan ajaran agama masing-masing. Kesadaran bermasyarakat, berbangsa dan bernegara. Membangun kehidupan atas dasar kerjasama umat beragama untuk mewujudkan persatuan dan kesatuan. Mengembangkan sikap kekeluargaan antar suku bangsa dan antar bangsa-bangsa.

Tanggung jawab daerah (lokal) dan nasional. Menjaga kehormatan diri dan bangsa. Mengembangkan sikap disiplin diri, sosial dan nasional. Mengembangkan kesadaran budaya daerah dan nasional. 
Mengembangkan perilaku adil dalam kehidupan. Membangun kerukunan hidup. Menyelenggarakan 'proyek budaya' dengan cara pemahaman dan sosialisasi terhadap simbol simbol identitas nasional, seperti bahasa Indonesia, lagu Indonesia Raya, bendera Merah Putih, lambang negara Garuda Pancasila, bahkan budaya nasional yang menggambarkan puncak-pucak budaya di daerah dan sebagainya (Kamal, 2018).

\section{SIMPULAN}

Pendidikan multikultural adalah proses pengembangan seluruh potensi manusia yang menghargai pluralitas dan heterogenitasnya dengan didasarkan pada prinsip-prinsip persamaan (equality), saling menghormati dan menerima serta memahami dan adanya komitmen moral untuk sebuah keadilan sosial.

\section{DAFTAR PUSTAKA}

Agus, M. (2016). Strategi Sekolah Dalam Pendidikan Multikultural. Jurnal Pendidikan Sekolah Dasar, 1(2) Sunarto. (2015). Sistem Pembelajaran PAI Berwawasan Multikultural. Lampung: IAIN Raden Intan Lampung

Samsul, N. (2002), Filsafat Pendidikan Islam. Jakarta: Ciputat Pers

Ahmad, T. (1992). Ilmu Pendidikan dalam Perspektif Islam Bandung: Remaja Rosdakarya

Ahmadi, (2005). Ideologi Pendidikan Islam. Yogyakarta: Pustaka Pelajar

Muhamad, M. (2013). Pendidikan Islam Berbasis Multikulturalisme. ADDIN, 7(1) Agus, M. (2016). Strategi Sekolah Dalam

Pendidikan
Multikultural. Jurnal Pendidikan Sekolah Dasar, 1(2)

Zubaidi. (2004). Telaah Konsep Multikulturalisme dan Implementasinya dalam Dunia Pendidikan. Hermina, 3(1)

Nana, S. (1997). Strategi Pembelajaran, Bandung: Falah Production

Ibrahim. (2008). Pendidikan Multikultural: Upaya Meminimalisir Konflik dalam Era Pluralitas Agama. $E L$ TARBAWI, 1(1).

Tilaar, H. A. R.. (2004). Multikulturalisme: Tantangan Global Masa Depan dalam Transformasi Pendidikan Nasional. Jakarta: Grasindo

Hamdan, H., B. (2018). Desain Pengembangan Pendidikan Multikultural Di Sekolah Dasar. Muhiddinur, K. (2018). Pengembangan Materi PAI Berwawasan Multikultural Sebagai Upaya Menanamkan Nilai-Nilai Keberagaman Siswa SMKN 1 Ampek Nagari. Edukasia: Jurnal Penelitian Pendidikan Islam, 13(1)

Hawi, A, \& Qolbi, K. (2017). Arah Pengembangan Pendidikan Agama Berwawasan Multikultural. Intizar, 23(1)

Mestika, Z. (2004). Metode Penelitian Kepustakaan. Jakarta: Yayasan Obor Indonesia 